\section{AL-AZHAR}

Assiut Dental Journal
The Official Publication of The

Faculty of Dental medicine.

Al-Azhar Assiut Uniuersity.

AADJ, Vol. 3, No. 1, April (2020) - PP. 1:5

ISSn 2682-2822

\title{
Radiographic Evaluation of Single Implant Retained Overdenture Using Locator Versus Ball and Socket Attachments
}

\author{
Mohammed A. Osman ${ }^{1}$, Diab F. Haddad ${ }^{1}$, Mohammed A. Quassemc ${ }^{1}$, Mostafa I. Fayadd ${ }^{1,2 *}$
}

Codex : 01/2020/04

Aadj@azhar.edu.eg

\section{KEYWORDS}

Implant, Overdenture,

Retention, Support,

Attachments,

Ball and Socket, Locators.

1. Department of Removable Prosthodontics, Faculty of Dental Medicine (Boys) Cairo, Al-Azhar University, Egypt.

2. Department of Substitutive Dental Science, College of Dentistry, Taibah University, kingdom of Saudi Arabia.

* Corresponding Author e-mail: dr.mifayad@azhar.edu.eg

\begin{abstract}
Aim: The aim of this study was to radiographically evaluate ball versus locator attachment systems for mandibular single implant-retained complete over denture. Subjects and Methods: Twenty completely edentulous patients were randomly selected from the Outpatient Clinic, Department of Removable Prosthodontics, Faculty of Dental Medicine, (Boys, Cairo), Al-Azhar University. The patients divided into groups, group I received single implant retained overdenture with ball and socket while group II received single implant retained overdenture with locator attachment. Radiographic evaluation was carried out with periapical radiograph using the extension cone parallel technique. Results: Group I recorded higher bone loss than group after one year of overdenture insertion and the difference was significant. Conclusion: Locator attachment provides optimal results regarding preservation of bone around implant fixture of implant retained overdenture than those with ball and socket attachment.
\end{abstract}

\section{INTRODUCTION}

Loss of teeth is one of the major handicaps in elderly patients, compromising their chewing efficiency and thus the nutritional status. For such people complete dentures are the source to rely on but unfortunately with conventional dentures, there are some issues of retention and stability ${ }^{[1,2]}$.

The concept of implant retained overdenture was documented to enhance the quality of life and oral health. But the major problem with over dentures was its high cost. Clinical studies have shown that single implant retained over denture is a viable alternative when cost is considered ${ }^{[3-6]}$.

A wide variety of commercially available attachment systems is used to connect implants to over dentures. Most commonly used attachments include stud, bar, magmatic, and telescopic attachments. Each of these types has owned its advantages, disadvantages, and special requirements efficiently to be used. ${ }^{[7]}$ 
Many studies compared the efficacy of different types of attachment systems and they found that single implant over dentures with dome type magnet or ball attachments had biomechanical effects similar to two-Implant over dentures. Attachment systems of larger dimensions provided higher retentive forces and that has stress breaking ability (ball attachment) provided optimal stress distribution ${ }^{[8,9]}$.

With new types of connectors regularly being introduced to the market, the efficiency of ball attachments is well-documented. In 2001, Zest Anchors introduced Locator attachment, which provides an improved design that combines the best features of the ball, ERA (extra-radicular attachment), and cap attachment types. The newly developed Locator attachment system has become widely applied. ${ }^{[10-12]}$

Therefore, this study was done to compare between different attachment systems for mandibular single implant-retained complete over denture, as regards to radiographic evaluation.

\section{PATIENTS AND METHODS}

Twenty completely edentulous patients with average age of 45-55 years free from any systemic diseases that might affect implant placement were randomly selected from the Outpatient Clinic, Department of Removable Prosthodontics, Faculty of Dental Medicine, Al-Azhar University (Boys, Cairo). Informed consent was obtained from all patients after an explanation of the methodology prior to enrolment in the study.

Prosthodontics phase of the treatment: An acrylic complete denture was constructed for each patient following the conventional steps for complete denture construction with bilateral balanced occlusion concept. After the denture was finished and polished, it inserted in the patient's mouth and verification of esthetics, retention, stability, occlusion, high spots and any sharp or overextension that may cause pain were done. Post insertion instructions were done; patients were instructed to wear the dentures till adaptation was acquired. Acrylic custom-made aiming device was constructed to aid in correct film positioning during radiographic evaluation.

\section{Implant placement:}

Following single stage surgical protocol, Single dental implant fixture (Dentis, Dalseo-gu,Daegu ,Korea) with Implant length $10 \mathrm{~mm}$, Implant diameter $3.7 \mathrm{~mm}$ were placed at midline of mandibular alveolar ridge. Patients were randomly allocated into two groups according to attachment used Group I: Patients received ball and socket attachment. Group II: Patients received locator attachment. Housings were created in the fitting surface of the denture to receive the female part or the attachments using auto- polymerizing acrylic resin.

\section{Observations:}

Radiographic examination of the crystal bone loss around the implant was carried out with film sensor (RVG 5200, Carestream Dental / Kodak. USA software), Aiming device with bite block and digital periapical film sensor inserted inside the patient's mouth then exposure was done using the extension cone parallel technique. Fig (1) and Fig (2).

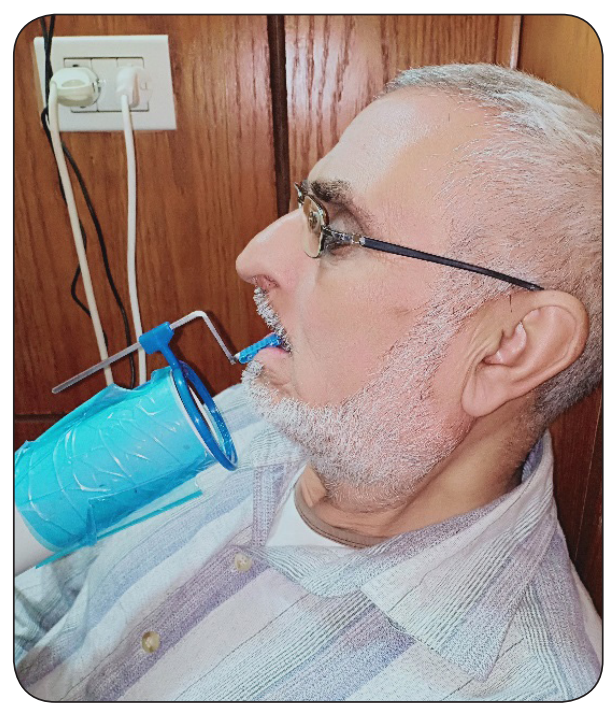

Fig (1): Aiming device carrying bite block with film sensor during exposure. 


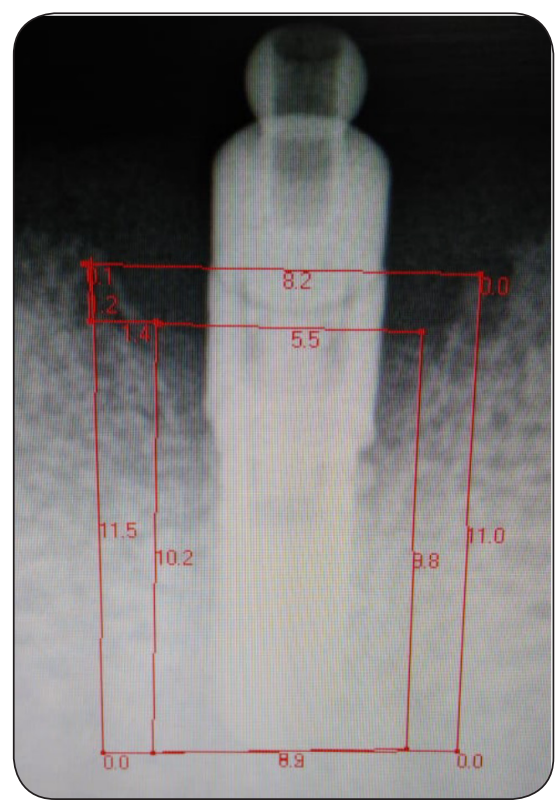

Fig (2): Crystal bone loss measuring.

\section{RESULTS}

The data were collected, tabulated and statistically analyzed using SPSS $^{\odot}$ for windows. The data distribution of normality was done by using Kolmogorov-Smirnov test. The test showed normal distribution of data and student t-test was used for statistical analysis. The significance level was set at $\mathrm{P} \leq 0.05$. Statistical analysis was performed with SPSS $^{\odot}$ Statistics Version 20 for Windows.

\section{Bone loss:}

Three months after loading, it was found that group1 (ball and socket) recorded a higher bone loss mean value $(0.12 \mathrm{~mm})$ than group2 (locator) $(\mathbf{0 . 1 1 4}$ $\mathrm{mm})$, the difference between the two groups was statistically non-significant as indicated by t-test as $(\mathrm{p}>0.05)$.

Six months after loading, it was found that group1 (ball and socket) recorded a higher bone loss mean value $(0.21 \mathrm{~mm})$ than group2 (locator) $(\mathbf{0 . 1 9} \mathrm{mm})$, the difference between the two groups was statistically non-significant as indicated by $\mathrm{t}$ test as $(\mathrm{p}>0.05)$.
Nine months after loading, it was found that group1 (ball and socket) recorded a higher bone loss mean value $(0.789 \mathrm{~mm})$ than group2 (locator) $(\mathbf{0 . 6 6} \mathrm{mm})$, the difference between the two groups was statistically significant as indicated by t-test as $(\mathrm{p}<0.05)$.

12 months after loading, it was found that group1 (ball and socket) recorded a higher bone loss mean value $(1.35 \mathrm{~mm})$ than group2 (locator) $(\mathbf{0 . 9 3 1} \mathrm{mm})$, the difference between the two groups was statistically significant as indicated by t-test as $(\mathrm{p}<0.05)$.

\section{DISCUSSION}

The implant-retained overdenture with single implant placed in the midline of the mandible has been shown to be a successful prosthetic treatment because of its relative simplicity, minimal invasiveness, economy, improved retention and stability. ${ }^{[13,14]}$

In this study each patient in group (I) received mandibular overdenture retained by ball attachments. Ball attachments are widely used because of their low-cost, ease of handling, minimal chair side time requirements and their possible applications with both root and implant retained prostheses ${ }^{[15]}$. Each patient in group (II) received mandibular overdenture retained by locator attachment system. Locator attachment system is an attachment system with self-aligning feature and has dual retention (inner and outer). The reduced height of this attachment is advantageous for cases with limited interocclusal space ${ }^{[16,17]}$.

Ball and socket attachment recorded a higher bone loss mean values than locator attachment. These results consistent with 3-dimentional finite element study compared between locator and ball and socket attachments which concluded that the locator attachments may provide an adequate attachment system with respect to reducing the stress on the implant body and supporting structures when compared with the ball attachments for 
implant-retained overdentures. ${ }^{[18]}$ However these results in consistent with three-dimensional finite element analysis evaluated the stress distribution and force distribution on the surrounding bones in ball and locator attachments in bone level and tissue level implants. In this study, the maximum amount of stress on the bone was for locator attachments. ${ }^{[19]}$ This difference in the results may be due to difference in study between clinical and lab studies and using different implant types.

\section{CONCLUSION}

Within the limitations of the present study, the following conclusions can be drawn:

1. Locator attachment provide optimal results regarding preservation bone around implant fixture of implant retained overdenture than those with ball and socket attachment.

2. Single implant overdenture is a successful economical treatment modality for completely edentulous patients suffering from impaired mandibular denture retention.

\section{REFERENCES}

1. Koole, S. and H. De Bruyn, Contemporary undergraduate implant dentistry education: a systematic review. Eur J Dent Educ, 2014. 18 Suppl 1: p. 11-23.

2. Reddy, N.S., et al., Epidemiological survey on edentulousness. J Contemp Dent Pract, 2012. 13(4): p. 562-70.

3. Barai, G.D., et al., FEM analysis of single implant retained mandibular overdenture with four different attachment types: A review. International J. of Healthcare and Biomedical Research, 2016. 4(2): p. 29-34.

4. Walton JN, Glick N, and M. MI., A Randomized Clinical Trial Comparing Patient Satisfaction and Prosthetic Outcomes with Mandibular Over Dentures Retained by One or Two Implants. Int J Prosthodont, 2009;22:331-9. 22: p. 331-339.

5. Chenga $\mathrm{T}$, et al., Use of A Single Implant to Retain Mandibular Overdenture: A preliminary clinical trial of 13 cases. J.Dental science, 2012. 7: p. 261-266.

6. Shajahan J U, et al., Single Implant Retained Mandibular Overdenture A Literature Review. Int J of Oral Health Dent. Int J of Oral Health Dent, 2015. 7: p. 261-266.
7. Ahmed Y A and A.F. K. Attachments Used with Implant Supported Over Denture. Int Dent \& Med J of Advan Res, 2016. 2: p. 1-5.

8. Cheng, T., et al., Patient satisfaction and masticatory efficiency of single implant-retained mandibular overdentures using the stud and magnetic attachments. J Dent. 40(11): p. 1018-23.

9. Kono, K., et al., In vitro assessment of mandibular single/ two implant-retained overdentures using stress-breaking attachments. Implant Dent. 23(4): p. 456-62.

10. Schneider, A.L. and G.M. Kurtzman, Bar overdentures utilizing the Locator attachment. Gen Dent, 2001. 49(2): p. 210-4.

11. Büttel AE, Bühler NM, and M. CP, Locator or Ball Attachment: A Guide for Clinical Decision Making. Schweiz Monatsschr Zahnmed, 2009. 119: p. 901-918.

12. Kleis WK, et al., A comparison Of Three Different Attachment Systems For Mandibular Two-Implant Over dentures: One-Year Report. Clin Implant Dent Relt Res., 2010. 12: p. 209-18.

13. Lee, E. and S.Y. Shin, The influence of the number and the type of magnetic attachment on the retention of mandibular mini implant overdenture. J Adv Prosthodont, 2017. 9(1): p. 14-21.

14. Mahoorkar, S., S. Bhat, and R. Kant, Single implant supported mandibular overdenture: A literature review. The Journal of the Indian Prosthodontic Society, 2016. 16(1): p. $75-82$.

15. Budtz and J. E., Prosthodontics for the Elderly: Diagnosis and Treatment. Chicago: Quintessence Publishing Co., Inc.; 2001.

16. Evtimovska E, et al., The change in retentive values of locator attachments and hader clips over time. J Prosthodont 2009. 18: p. 479-83.

17. Pasciuta M, Grossmann Y, and F. IM., A prosthetic solution to restoring the edentulous mandible with limited interarch space using an implant-tissue-supported overdenture: A clinical report. J Prosthet Dent 2005. 93: p. 116-20

18. Iman A. Eltaftazani, Amal H. Moubarak, and M. ElAnwar, Locator Attachment versus Ball Attachment: 3-Dimentional Finite El ement Study. E.D.J., 2010. 57: p. $2-13$.

19. Mansour Rismanchian, et al., Stress Analysis of Ball and Locator Attachments and Bone in Overdenture Supported by Tissue Level and Bone Level Implants: A Three-dimensional Finite Element Analysis. Journal of International Oral Health, 2016. 8: p. 952-57. 
مجلة أسيوط لطب الهب الأسنان
النشر الرسمي لكلية طب الأسنان

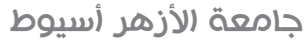

\title{
تقييم إشعاعي للغرسات السنية المفردة المثبتة لأطقم الاسنان السفلية والمثبتة بنظامي اللوكاتور ونظام الكرة والمرفق
}

\author{
محمد عبـاس عثمان1، دياب فؤاد الحداد1 ، محمد عبـدالله قاسم1، مصطفى ابراهيم فياض1،1*2

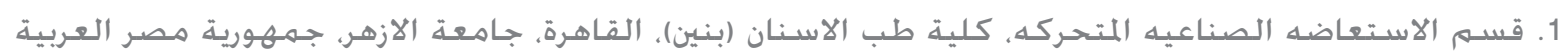

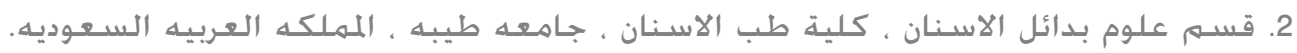

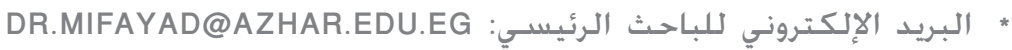

(الملخص :

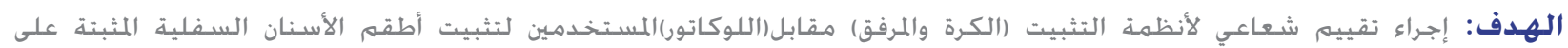
غرسـة سنية واحده.

المواد والاسـاليب:تم اختيار المرضى بطريقة عشـوائية من العيادة الخارجية لقسهم الاستعاضة السنية المتحركة .كلية طب أسنان. (بنين ،

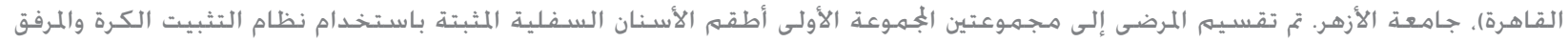

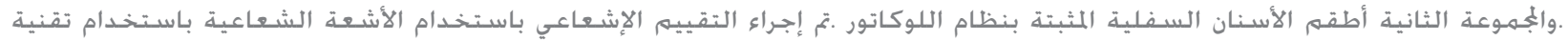
موازية مخـروط التمديد.

النتائج: سجلت الجُموعة الأولى نتائج فقدان عظام أعلى من الجُموعة بعد عام واحد من الدراسـة وكان الفرق كبيرًا.

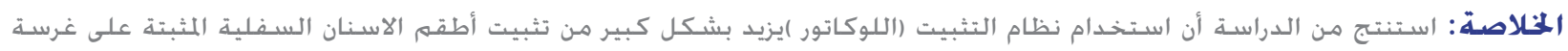

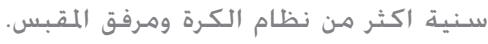
الكعلمات المفتاحية :غرسـه سـيه, اطقهم الاسـنان السفلية المثبتة على غرسـة سـية, تثبيت, جودة الحياة المرتبطة بالصحة الفمهوية

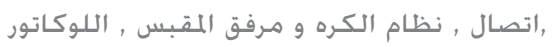

